How to cite this article

Idris, S., \& Kabiru, S.A. (2019). Towards promoting rural infrastructure for poverty reduction: Analysis of FADAMA III small-scale community-owned infrastructure in Kaduna and Sokoto states, Nigeria. Journal of International Studies, 15, 145-164. https:// doi.org/10.32890/jis2019.15.10

\title{
Towards Promoting Rural Infrastructure for Poverty Reduction: Analysis of $F A D A M A$ III Small-Scale Community-Owned Infrastructure in Kaduna and Sokoto States, Nigeria
}

\author{
${ }^{1}$ Sa'idu Idris \& ${ }^{2}$ Salisu Ahmed Kabiru \\ ${ }^{1}$ Department of Public Administration \\ Usmanu Danfodiyo University, Sokoto-Nigeria \\ ${ }^{2}$ Department of Public Administration \\ Umaru Musa Yar'adua University Katsina, Nigeria \\ ${ }^{2}$ Corresponding author: salisu.ahmed@umyu.edu.ng \\ DOI: https://doi.org/10.32890/jis2019.15.10
}

Received: 16/2/2019

Revised: 20/11/2019

Accepted: 11/12/2019

Published: $31 / 12 / 2019$

\begin{abstract}
This study is aimed at assessing the impact of the Third National Fadama Development Project (NFDP III) on the provision of small-scale community-owned Infrastructures (SCIs) for poverty reduction. The sector goal of NFDP III is to reduce poverty by improving the living conditions of the rural poor; contribute to food security and increase access to rural infrastructures. The study made use of questionnaires to generate primary data from 245 respondents whilst project implementation manuals, appraisal reports, baseline and midline surveys, etc. constituted the secondary data. The study found that outcome of the NFDP III had a profound impact on the beneficiaries, notably crop farmers and livestock owners. For example in Kaduna State, the income of crop farmers increased by 199\% and livestock owners by 221\%. In Sokoto State, the income of crop farmers increased by 225\% and livestock owners by 315\%. The food security situation of the crop farmers and livestock owners had improved greatly by about $84.4 \%$ and $98.3 \%$, respectively. While the socio-economic conditions of the crop farmers and livestock owners had improved significantly by $74.2 \%$ and $95.7 \%$, respectively. The study recommends that to further sustain the impetus created by the NFDP III on poverty reduction in Nigeria, the federal, state and local governments should as a matter of concern, extend their commitment beyond facilitating the provision of rural infrastructure to those of scaling-up the levels of provision, maintenance, and management and poverty reduction so as to remain part of national development goals.
\end{abstract}

Keywords: Rural infrastructure, small-scale community-owned infrastructure, poverty reduction, development project. 


\section{Introduction}

In spite of the surfeit of national and international statements, summits, policies and programmes for reducing poverty, the menace of poverty especially in the countryside remains a huge developmental challenge facing the global community. It is an undisputable fact that, the countryside of any developed or developing nation lacks the necessary social amenities and infrastructures necessary for decent living. Although so many factors could have contributed to the incidence of rural poverty, it is glaring to note from the World Bank (2016) report that amongst other factors, insufficient or lack of socio-economic infrastructure that could stimulate and facilitate socio-economic activities in the rural areas were apparently amongst the factors that caused the rural poor to remain trapped in the vicious cycle of poverty, for years.

Therefore, in order to promote the livelihood of the rural poor, the Federal Government of Nigeria (FGN) and the World Bank designed the National Fadama Development Projects (NFDPs) beginning in the early 1990s. The sector goal of the NFDPs is to reduce poverty by improving the living conditions of the rural poor; contribute to food security and increase access to rural infrastructure (FGN-Project Implementation Manual, 2009). Essentially, participation in the NFDPs is categorized into two (2): i) zones endowed with humidity favourable for irrigational activities classified as Core States, and ii) other States that meet certain requirements for participation as Facility States. The criteria is based on: (a) a written proposed action plan for both up-stream and down-stream post-harvest activities; (b) a written commitment for regular payment of counterpart funds deducted at the source (at the Ministry of Finance); (c) evidence of viable and active FRUs or other economic groups; (d) evidence of the existence of conflict management committees, and (e) completion of a detailed assessment of existing fadama infrastructures.

Therefore based on the above stated criteria, Kaduna State participated in the NFDP II and NFDP III as one of the Facility States. About eighty percent $(80 \%)$ of the population of the people in the State is engaged in farming thereby producing both cash and food crops as well as livestock activities (www.kadunastate.gov.ng.). On the other hand, Sokoto State participated in NFDP I and NFDP III as one of the Core States. The major occupations of the people in the State include arable and livestock farming. The Sokoto-Rima River and its numerous tributaries runs through some low-lying valleys, the length of three miles (five kilometers) with the Bakolori Dam which provides year-round irrigation to the Sokoto Rima Basin (www.sokotostate.gov.ng).

Rural infrastructures in general are development projects, either large-scale or small-scale that significantly support and improve the socio-economic conditions of the people. With particular reference to NFDPs, small-scale community-owned infrastructures consist of low cost irrigation systems, feeder roads and drainage systems, and other infrastructures support sub-components such as ventilated improved pit (VIP) latrines; water point boreholes; cold storage rooms and cooling sheds at all markets (FGN, Project Implementation Manual, 2009). For example, road construction improves access to other basic infrastructures. 
Investments in storage facilities can reduce the risk of food spoilage and other losses, higher gains for agricultural produce which in turn, results in increased productivity and higher income. These cyclical chains, will improve the general well-being of rural dwellers. This study, therefore, attempts to assess the extent to which NFDP III contributed to poverty reduction through the provision of small-scale community-owned infrastructures (SCIs) for the period 2009-2016.

\section{Problem Statement}

Whilst rural transformation is greatly influenced by the availability, type, quality and quantity of infrastructural facilities and the regularity of their maintenance, in Nigeria, such infrastructures like access roads, drainage and culverts, open market stalls, water point boreholes, etc., are grossly inadequate and the maintenance of these basic infrastructures is largely carried out by the government without consultation with the actual beneficiaries. This practice does not recognize beneficiary communities to contribute, prioritize, or identify the type and quality of a specific infrastructure needed nor does it in any way tasked them with project maintenance. It has been estimated that about $70 \%$ of the road networks in Nigeria are in poor condition and that road density is one of the lowest in sub-Saharan Africa. For example, more than half of the $200,000 \mathrm{~km}$ feeder and access roads constructed nationwide by the now defunct Directorate for Food, Roads and Rural Infrastructure (DFRRI) are virtually lost after two decades due to poor maintenance (AfDF, 2003).

Outcome of baseline surveys which tracked the extent of infrastructural deficits in the following order revealed that: i) between 40 and $65 \%$ of the beneficiary communities of Kaduna and Sokoto states lacked good fadama and access roads; ii) more than 45 to $55 \%$ of the village markets were generally ill-equipped to accommodate farm produce, especially perishables, and iii) an estimated 10 to $15 \%$ of the total production of grains were lost or wasted annually due to poor access roads, storage facilities and lack of marketing infrastructures, etc. (SFDOs, Kaduna and Sokoto, 2009). The concern of this study is to ascertain to what extent NFDP III has contributed to poverty reduction through the provision of SCIs in the beneficiary communities of Kaduna and Sokoto states, Nigeria. The process of finding answers to this fundamental question will reveal whether there is any significant difference in the level of provision of SCIs amongst the beneficiaries in the two (2) states under study.

\section{Objectives of the Study}

i. To examine the extent of the provision of SCI in reducing the incidence of poverty amongst NFDP III beneficiaries, and

ii. To ascertain whether there is any significant difference in the level of provision of SCIs amongst NFDP III beneficiaries in Kaduna and Sokoto states, Nigeria. 


\section{Research Hypothesis}

$\mathrm{H}_{\mathrm{o}}$ : Level of provision of SCIs has no significant impact on reducing the incidence of poverty of NFDP III beneficiaries in Kaduna and Sokoto States, Nigeria.

\section{Significance and Scope of the Study}

No doubt, the development of rural infrastructure is a cornerstone to enhancing the living standards of the rural dwellers as their poor state and infrastructural deficits further exacerbate the persistence of poverty. There are of course, empirical evidences supporting the above statement. For example, Ale's (2011) study reveal that, the level of infrastructure development in rural Nigeria is nothing but poor and that is why there is the crisis of food security, city congestion and prevalence of rural poverty in the country. Adenuga (2012) also find that the state of the road infrastructure in almost every part of Nigeria is poor, as only $12 \%$ of the rural road networks are tarred. A study by Olagunju's (2014) also reveal that, most essential infrastructures such as roads, markets, water pipes, etc., in rural Nigeria are grossly inadequate. Beyond these facts, however, the researcher discovered that, there is a dearth of scholarly investigation on assessing the level of provision of NFDP III's SCIs and its impact on poverty reduction especially by comparing a Facility State against a Core State within the same geo-political (north-west) zone. In particular, the findings of this study could facilitate policy makers/development administrators to chart a course of action that would help sustain and scale-up the impact NFDP III in promoting poverty reduction in Nigeria. Therefore, the relevance of this study lies in its focus towards attempts to link the provision of SCIs and poverty reduction.

The scope of the study covered SCI components of NFDP III for a period of seven (7) years (2009-2016) i.e. four (4) years of phase I of NFDP III implementation period (2009-2013) and three (3) years after NFDP III implementation (2013-2016). This was to determine the level of impact of NFDP III's SCIs provision during and after project implementation. Kaduna and Sokoto states, Nigeria were purposively selected from the same geo-political zone to establish whether significant differences exist in the level of provision of SCIs amongst the project beneficiaries in the core and facility states.

\section{Literature Review}

There is agreement amongst scholars that the poor tier of any society is most likely food insecurity. When hunger is excised from poverty, the burden of poverty is light. So, lack of food is the most critical dimension of poverty. However, in the search for theoretical and empirical links between improvements in the living conditions of people, rural infrastructure is identified as the single most important factor. Along this line of reasoning, there is broad agreement that poverty should be viewed from a basic needs approach which is understood 
to include factors such as basic health care, education, potable water and access roads, etc. In the context of poverty reduction, Calderón and Serve (2008) categorized infrastructural facilities to include economic infrastructures such as credit, loan, production support; physical infrastructures such as roads, irrigation facilities; support service infrastructures such as market services, etc. This classification is of immense importance because when the socio-economic status of people is promoted significantly, their well-being gets improved, generally. Madu (2007) observed that, the importance of rural infrastructure provision resided in its capacity to sustain peoples' daily activities, improve the quality of their lives and economic base in the rural areas. In fact, the quality of life and means of livelihood of the rural dwellers can be assessed by analyzing the availability/adequacy and quality of infrastructural facilities at their disposal.

The relationship between infrastructure and poverty has been demonstrated by Ogun (2010) based on data related to the 1970-2005 period which found that development in social and physical infrastructure significantly reduced poverty in the urban areas of Nigeria. Similarly, Calderón and Servén (2010) also established that increased access to essential infrastructure services could reduce inequality, foster inclusion and support poverty reduction efforts. Adeoye, Balogun and Carim-sanni (2011) used the NFDP II in Nigeria and found that more than half $(59.1 \%)$ of the villagers that participated in the NFDP II had more infrastructures than non-fadama villages. Moreover, they were found to be significantly better-off in a number of areas including agricultural production, and household income. In Ethiopia, Kifle (2012) found that access roads induced substantially higher rural income growth than what was reported by previous studies in that road induced factor of production returns on land and labour. In Nigeria, Adepoju and Timothy (2013) found that infrastructure is known to impact welfare in three basic respects. It has basic consumption value that affects utility derivable from existing and budgeted incomes; its availability affects productivity and the capacity to earn income, and it also affects households and national stock in real wealth in the entire economy and it has multiple effects on health and quality of life.

A study by Hastuti (2016) has also proven that the larger the paved area (good or quality) then the opportunity for non-poor people in the region increased. This is because access roads have an important role in the economic, social, cultural, environmental, political, defense and security, as well as the welfare of the people. Roads are also the distribution infrastructure of goods and services which serve as the lifeblood of the community. Thus with the availability of access roads people can perform activities easily including access their daily needs and reach the center of the economy, facilitate the course of productivity of goods and services. The study, therefore, established that the more extensive the quality of roads, the higher the chances of improving the living conditions of the rural populace; accelerating agricultural growth and enhancing economic activities.

Marinho, et al., (2017) in his research in Brazil also found that infrastructure has affected the temporal trajectory in Brazil, which means there is a positive change after the implementation of infrastructure improvements via an index that consisted of transportation, energy and 
mineral resources, communication and health, sanitation, gross domestic product per capita and education to reduce poverty in Brazil.

Based on the provisions of the Central Bureau of Statistics in Indonesia, there was a decline in both rural and urban poverty from 2006 to 2015. During the ten year period, rural poverty decreased by $7.6 \%$ while urban poverty decreased by $5.2 \%$. Rural areas had a more significant poverty reduction compared to urban areas. This fact is in line with the expenditure of more infrastructures for rural rather than urban areas to reduce the incidence of rural poverty. This concurred with Prawesti and Hermawan (2017) in their research on infrastructure development and poverty reduction in Java. Rural roads that increased connectivity for rural areas significantly increased access to markets and related knowledge; they also enhanced household income, reduced poverty and improved access to health care and education (Schweikert \& Chinowsky, 2012). Therefore, the aformentioned studies have highlighted the relationship between rural infrastructure and poverty reduction from various angles.

\section{Theoretical Framework}

The theoretical framework adopted for the study is the Economic Theory of Infrastructure and Commons Management. This theory was developed by Frischmann in 2005. Frischmann (2005) developed an economic theory of infrastructure that provides a better understanding of societal demands for infrastructural facilities. The term infrastructure, generally conjures the notion of physical resource systems made by humans for public consumption. The theory has four core components: public access to infrastructure; the value of infrastructure when used as input into a wide variety of productive processes; the management of infrastructure resources and people's empowerment. Public access to infrastructure applies to certain public goods such as road networks, bridges, culverts, drainages, cooling shades, improved ventilated pit latrines, market water point boreholes, etc. are made available and are enjoyed by members of the community. Infrastructure resources according to Frischmann (2005) constitute an important class of resources on which society should place "a very high value on public access." Frischmann (2005) viewed infrastructures as fundamental resources that generate value when used as input into a wide range of productive processes. Managing infrastructure resources should be conducted in an openly accessible manner so that people are empowered to engage in the production of certain goods that are desirable.

In relation to this study, participation in NFDP III was meant for beneficiaries to analyze their existing situations, identify and prioritize sub-project(s) needed by the community. In fact, the appeal of the community-driven development (CDD) model arose mainly from recent efforts to empower local communities to participate in decision-making and implementation of development programmes. Khwaja (2001) observed that projects initiated and managed by communities are more sustainable than those designed and managed by governments because of better maintenance. Therefore, sustainable poverty reduction is 
not possible without empowerment of the poor. Infrastructure resources such as fadama and access roads, bridges and culverts, water point boreholes, market stalls, cooling sheds, spillways and distribution canals, etc. when adequately provided or significantly promoted will serve as inputs that can generate value in the productive processes (human consumption and industrial activities), stimulate growth in agricultural and industrial sectors as well as improve the living conditions of individuals. In particular, the provision of access roads and market infrastructures are largely public goods which generate positive externalities that benefit society as a whole.

\section{Methodology}

This study is a survey research with Grossman's (1994) reflexive comparison design. Reflexive design treats project participants to serve as both treatment and reference groups. The strength of this methodology lies in the analysis of the observed changes in living conditions of the beneficiaries (pre- to post-project period) which should be conducted to determine whether changes can be attributed to the programme. However, the focused group of this study is the Fadama Community Associations (FCAs) and their constituent units, the Fadama User Groups (FUGs). The target project beneficiaries are presented in Table 1.

Table 1

FCAs and FUG Members According to States and Local Governments

\begin{tabular}{|c|c|c|c|c|}
\hline State & $\begin{array}{l}\text { Local } \\
\text { Government }\end{array}$ & FCA/FUGs & Population & $\begin{array}{c}\text { Sample Size of } \\
\text { Respondents }\end{array}$ \\
\hline
\end{tabular}

\begin{tabular}{llcc} 
Kaduna Igabi & Jaji District Union Cooperative & & \\
& Society, FCA & 25 & 9 \\
& Kalgo Multi-purpose CS Ltd & 25 & \\
& Jaji Multi-purpose Fadama Farmers & 25 & 9 \\
& CS Ltd & 25 & \\
& Inganci Multi-purpose Fadama & & 8 \\
& Farmers CS Ltd & 25 & 9 \\
& Jaji Women Multi-purpose CS Ltd & 9 \\
& Jaji-Alheri Fadama Farmers CS Ltd & 25 & 9 \\
& Jaji-Alheri Fadama Farmers CS Ltd & 25 & \\
& Jaji-Alheri Fadama Farmers CS Ltd & 25 & $\mathbf{4 3}$ \\
\hline Kubau & Total & $\mathbf{1 2 5}$ & (continued)
\end{tabular}




\begin{tabular}{|c|c|c|c|}
\hline State & $\begin{array}{ll}\text { Local } & \text { FCA/FUGs } \\
\text { Government }\end{array}$ & Population & $\begin{array}{l}\text { Sample Size of } \\
\text { Respondents }\end{array}$ \\
\hline
\end{tabular}

\begin{tabular}{|c|c|c|c|c|}
\hline & & $\begin{array}{l}\text { Likarbu Tomatoes Production } \\
\text { Cluster Cooperative Union, FCA }\end{array}$ & & \\
\hline & & Gimbawa Fadama Farmers CS Ltd & 25 & 9 \\
\hline & & Zuntu-Koni Multi-purpose CS Ltd & 25 & 8 \\
\hline & & Wazabi Nasara Tomatoes CS Ltd & 25 & 8 \\
\hline & & Durumi Fadama Farmers CS Ltd & 25 & 9 \\
\hline & & $\begin{array}{l}\text { Zuntu-Central Fadama Farmers CS } \\
\text { Ltd }\end{array}$ & 25 & 9 \\
\hline & & Total & 125 & 43 \\
\hline & & $\begin{array}{l}\text { Gazara Fadama Farmers } \\
\text { Cooperative Limited, FCA }\end{array}$ & & \\
\hline & & Anguwan Galadima Fadama CS Ltd & 25 & 9 \\
\hline & & Maraban T/Yari Fadama CS Ltd & 25 & 9 \\
\hline & & Anguwan Wakili WMPCS Ltd & 25 & 9 \\
\hline & & $\begin{array}{l}\text { T/Wada Makarfi-North Fadama CS } \\
\text { Ltd }\end{array}$ & 25 & 8 \\
\hline & & Anguwan Galadima II WMPCS Ltd & 25 & 8 \\
\hline & & Total & 125 & 43 \\
\hline & & $\begin{array}{l}\text { Total target beneficiaries, Kaduna } \\
\text { State }\end{array}$ & 375 & 129 \\
\hline Sokoto & Sokoto-south & $\begin{array}{l}\text { Karaye-shiyar Jariri Cooperative } \\
\text { Union, FCA }\end{array}$ & & \\
\hline & & Women Granders CS Ltd & 25 & 9 \\
\hline & & Himma Rice Farmers CS Ltd & 25 & 9 \\
\hline & & $\begin{array}{l}\text { Minannata Women Sheep Rearing } \\
\text { CS Ltd }\end{array}$ & 25 & 9 \\
\hline & Wamakko & $\begin{array}{l}\text { Rice Farmers Association T/Wada } \\
\text { CS Ltd }\end{array}$ & 25 & 8 \\
\hline & & $\begin{array}{l}\text { Kungiyar Manoman Shinkafa, Sh/ } \\
\text { Jariri CS Ltd }\end{array}$ & 25 & 8 \\
\hline & & Total & 125 & 43 \\
\hline & & $\begin{array}{l}\text { Arkilla III Cooperative Union, } \\
\text { FCA }\end{array}$ & & \\
\hline & & Sheep and Goat Rearing CS Ltd & 25 & 8 \\
\hline & & Youth Sheep Rearing CS Ltd & 25 & 9 \\
\hline & & Gidan Boka Rice Farmers CS Ltd & 25 & 9 \\
\hline & & Wamakko Women Poultry CS Ltd & 25 & 8 \\
\hline
\end{tabular}


Towards Promoting Rural Infrastructure for Poverty Reduction: Analysis of FADAMA III Small-scale Community-owned Infrastructure in Kaduna and Sokoto States, Nigeria

\begin{tabular}{|c|c|c|c|c|}
\hline State & $\begin{array}{l}\text { Local } \\
\text { Government }\end{array}$ & FCA/FUGs & Population & $\begin{array}{l}\text { Sample Size of } \\
\text { Respondents }\end{array}$ \\
\hline & & Ni'ima Poultry Farmers CS Ltd & 25 & 8 \\
\hline & & Total & 125 & 42 \\
\hline & Yabo & $\begin{array}{l}\text { Ruggar Iya I, Cooperative Union, } \\
\text { FCA }\end{array}$ & & \\
\hline & & Dagawa Pepper Farmers CS Ltd & 25 & 8 \\
\hline & & Rugga Iya Sheep Rearing CS Ltd & 25 & 8 \\
\hline & & $\begin{array}{l}\text { Dagawa Onion Fadama Farmers CS } \\
\text { Ltd }\end{array}$ & 25 & 8 \\
\hline & & $\begin{array}{l}\text { Dagawa Women Cattle Rearing CS } \\
\text { Ltd }\end{array}$ & 25 & 8 \\
\hline & & Dagawa Sheep Rearing CS Ltd & 25 & 8 \\
\hline & & Total & 125 & 40 \\
\hline & & $\begin{array}{l}\text { Total target beneficiaries, Sokoto } \\
\text { State }\end{array}$ & 375 & 125 \\
\hline & & $\begin{array}{l}\text { Grand Total of target population, } \\
\text { Kaduna and Sokoto states }\end{array}$ & 750 & 254 \\
\hline
\end{tabular}

Source: SFDO, Kaduna and Sokoto states (2014), Researchers' Survey, 2017

Based on Table 1, the study had 6 FCAs, 3 each from Kaduna and Sokoto states consisting of 5 FUG each per FCA, making up 15 FUGs per state, 30 FUG units for the two (2) states under study. The parent population of the six (6) FCAs consisted of 750, 375 per state. Krejcie and Morgans' (1970) population and sample size table was used to draw the sample size. Based on the table values, 254 (34\%) project beneficiaries were administered questionnaires; out of which 245 were duly filled and returned (128 Kaduna State, 117 Sokoto State). The questionnaire was structured using a Likert (1932) scaling method to enable respondents to express their level of assessment in various degrees of intensity from very high, high, average, low, to very low. Purposive and cluster sampling techniques were used in conducting this study. Kaduna and Sokoto states were purposively selected, likewise the selection of three (3) LGAs per state (One LG each) based on the intensity of fadama activities. The sampled FUGs were clustered according to their respective FCAs. From each of the six (6) FCAs, five (5) numbers of FUGs each were randomly selected.

Data for the study was presented and analyzed using both descriptive and inferential statistics. Simple percentage and frequencies were used to depict the bio data of the respondents whilst mean and standard deviation were used to answer the research questions. Pearson's Product Moment Correlation (PPMC) statistics was used to test the veracity of the conjectural statement. On the other hand, an independent sample $t$-test was also used to test whether there was any significant difference in the level of provisions of NFDP III activities 
amongst the project beneficiaries in Kaduna and Sokoto states, Nigeria. To test the null hypothesis, an alpha value of 0.05 level of significance was used. The decision is "accept $\mathrm{H}_{0}$ if the $\mathrm{p}$-value is less than or equal to the alpha value. Conversely, the $\mathrm{H}_{\mathrm{o}}$ will be rejected if the p-value is above or equal to the preset threshold value $(0.05)$."

\section{Results and Discussion}

To what extent has NFDP III contributed to poverty reduction through the provision of SCIs in the beneficiary communities of Kaduna and Sokoto states, Nigeria?

Table 2

Analysis of Mean Distribution on SCI and Poverty Reduction

\begin{tabular}{|c|c|c|c|c|c|c|c|c|c|}
\hline \multirow[t]{2}{*}{$\mathrm{s} / \mathrm{n}$} & \multirow[t]{2}{*}{ Item } & \multicolumn{5}{|c|}{ Response category } & \multirow[t]{2}{*}{ Mean } & \multirow[t]{2}{*}{ Std.dev } & \multirow[t]{2}{*}{ Remarks } \\
\hline & & $\mathrm{VH}$ & $\mathrm{H}$ & $\mathrm{Av}$ & Low & $\mathrm{VL}$ & & & \\
\hline 1 & $\begin{array}{l}\text { Level of provision, community- } \\
\text { owned infrastructure - access } \\
\text { road, culverts, drainage } \\
\text { systems, etc. }\end{array}$ & 4 & 29 & 165 & 42 & 5 & 2.9388 & .0194 & Negative \\
\hline 2 & $\begin{array}{l}\text { Level of provision, } \\
\text { infrastructure support sub- } \\
\text { components - VIP latrine, cold } \\
\text { storage, cooling sheds, water } \\
\text { point boreholes at markets, etc. }\end{array}$ & 2 & 5 & 85 & 109 & 44 & 2.2327 & .0741 & Negative \\
\hline 3 & Level of utilization of SCIs & 44 & 136 & 46 & 15 & 4 & 3.8204 & 1.0121 & Positive \\
\hline 4 & $\begin{array}{l}\text { Reduction in time (to market } \\
\text { and wait time) and transport } \\
\text { costs (reduced fare prices) due } \\
\text { to increased availability of } \\
\text { SCIs }\end{array}$ & 4 & 160 & 69 & 10 & 2 & 3.6286 & 0.813 & Positive \\
\hline 5 & $\begin{array}{l}\text { Improved access to wider } \\
\text { markets for agricultural } \\
\text { products }\end{array}$ & 2 & 173 & 66 & 2 & 2 & 3.6980 & 0.6416 & Positive \\
\hline 6 & $\begin{array}{l}\text { Reduction in rural-urban } \\
\text { migration }\end{array}$ & 5 & 91 & 131 & 13 & 5 & 3.3184 & 0.877 & Positive \\
\hline 7 & $\begin{array}{l}\text { Ability to send children to } \\
\text { school }\end{array}$ & 10 & 173 & 52 & 7 & 3 & 3.7347 & 0.646 & Positive \\
\hline 8 & $\begin{array}{l}\text { Ability to participate in social } \\
\text { activities, pilgrimages }\end{array}$ & 16 & 21 & 69 & 99 & 40 & 2.4857 & 1.074 & Negative \\
\hline 9 & $\begin{array}{l}\text { Participation in political } \\
\text { activities }\end{array}$ & 43 & 19 & 52 & 68 & 63 & 2.6367 & 1.0101 & Negative \\
\hline & Cumulative mean & & & & & & 3.166 & & Positive \\
\hline
\end{tabular}

Decision mean $=3.000$ 
As can be seen from Table 2, the respondents believed that provision of SCI by NFDP III has significantly impacted on their well-being. The cumulative mean response of 3.166 which is above the 3.000 decision mean lends credence to this assertion. In specific terms, the respondents rated the level of utilization of SCI, highly. This item showed the highest mean response of 3.8204 with details showing that whilst 44 rated this as very high, another 136 respondents rated it as high against 46 who rated it average and the remaining 15 and 4 of the respondents rated it as low and very low, respectively. In the same vein, respondents who had the ability to send their children to school had the second highest mean of 3.7347 with details showing that whilst 10 rated it as very high, 173 rated it as high against 52 who rated it average and the remaining 7 and 3 of the respondents rated it as low and very low, respectively.

In summary, the provision of SCI had significantly reduced the incidence of poverty of NFDP III beneficiaries through: i) improved access to wider markets for agricultural products; ii) changes in socio-economic status of the beneficiaries, and iii) reduction in rural-urban migration. The impact of these changes had a direct and positive effect on the livelihoods of the beneficiaries. They included: reduction in time (to market and wait time, average of 5 minutes). The provision of drainage systems which facilitated easy access to farmlands, access roads to the market and to take children to and from school to halt intergenerational poverty, had facilitated non-farm economic activities which in turn, led to higher income and economic prosperity.

Table 3

t-test Distribution on the Difference in the Level of Provision of SCIs amongst NFDP III Project Beneficiaries

\begin{tabular}{lcccccccc}
\hline \multicolumn{1}{c}{ Variable } & State & $\mathrm{N}$ & Mean & Std.dev & Std.err & df & T & $\mathrm{p}$ \\
\hline $\begin{array}{l}\text { Difference in the } \\
\text { level of provision of }\end{array}$ & Kaduna & 128 & 30.2813 & 2.92138 & .25822 & & & \\
$\begin{array}{l}\text { SCIs amongst NFDP } \\
\text { III beneficiaries }\end{array}$ & & & & & & 243 & 7.872 & 0.000 \\
\hline
\end{tabular}

Results of the independent sample $t$-tests showed that significant difference existed in the level of provision of SCI amongst beneficiaries in Kaduna and Sokoto states. The reason was that the computed means in the levels of provision of SCI differed significantly for Kaduna and Sokoto states, 30.2813 and 26.8803, respectively. This was a result of income differential therefore beneficiaries from Kaduna State had the resources to raise the $10 \%$ shares of counterpart funding, and hence the level of provision of SCIs was higher from beneficiaries in Kaduna State than those from Sokoto State. One other possible reason was that, beneficiaries covered by the study from Kaduna State were largely crop farmers whilst those from Sokoto were more engaged in livestock activities and as such; the adoption of 
agricultural technology in terms of crop multiplication favoured the crop owners more than the livestock owners.

Besides finding out differences in the level of provisions of NFDP III supported activities, the study further integrated our analysis with NFDP III's PDOs of increasing the income of the beneficiaries on a sustainable basis to reduce rural poverty and to contribute towards promoting food security. Results of further analyses on changes in beneficiaries' income, extent of food security and socio-economic conditions of NFDP III beneficiaries are shown in Tables 4, 5, 6, 7, 8 and 9.

Table 4

Analysis of Changes in Beneficiaries'Income

\begin{tabular}{|c|c|c|c|c|c|}
\hline & & Kaduna & State & & \\
\hline $\begin{array}{l}\text { Average } \\
\text { Income }\end{array}$ & $\begin{array}{l}\text { Baseline, } \\
2009\end{array}$ & $\begin{array}{l}\text { Midline, } \\
2011\end{array}$ & $\begin{array}{l}\% \text { increase in } \\
\text { income (baseline } \\
\text { to midline) }\end{array}$ & $\begin{array}{l}\text { Income, } 3 \\
\text { years after } \\
\text { NFDP III, } 2016\end{array}$ & $\begin{array}{l}\% \text { increase in } \\
\text { income (baseline to } \\
3 \text { years after project) }\end{array}$ \\
\hline $\begin{array}{l}\text { Crop } \\
\text { farmers }\end{array}$ & $\begin{array}{l}\text { N116, } \\
663.50\end{array}$ & $\begin{array}{l}\approx 209, \\
457.00\end{array}$ & $79.5 \%$ increase & $\mathrm{N} 349,332.00$ & $199 \%$ increase \\
\hline $\begin{array}{l}\text { Livestock } \\
\text { owners }\end{array}$ & $\begin{array}{l}\$ 92, \\
190.20\end{array}$ & $\begin{array}{l}¥ 121, \\
820.00\end{array}$ & $32.13 \%$ increase & $\$ 296,144.00$ & $221 \%$ increase \\
\hline $\begin{array}{l}\text { Non-farm } \\
\text { income }\end{array}$ & $\begin{array}{l}\text { N135, } \\
150.00\end{array}$ & $\begin{array}{l}N 155, \\
042.00\end{array}$ & $14.7 \%$ increase & N210, 280.10 & $55.5 \%$ increase \\
\hline
\end{tabular}

Source: Baseline and Midline Surveys (KDSFDO, 2009; 2011); Researchers' Survey, 2017

As can be seen in Table 4 the NFDP III had significantly impacted on its direct beneficiaries' income levels from baseline to midline. Crop farmers from Kaduna State secured 79.5\% increase in income whilst livestock owners achieved $32.13 \%$ increase in income from baseline to midline. For non-farm economic activities, beneficiaries attained $14.7 \%$ increase in income as a result of participation in the NFDP III. The information was gathered from the beneficiaries during oral interviews three years after the project. Crop farmers attained $199 \%$ increase in income from baseline whilst livestock owners achieved $221 \%$ increase in income. Beneficiaries of non-farm economic activities had an average increase of $55.5 \%$ as compared to their income at baseline.

As can be seen in Table 5, NFDP III had significantly impacted on its direct beneficiaries' income levels from baseline to midline. Crop farmers from Sokoto State had a 112\% increase in income whilst livestock owners had a $66.9 \%$ increase from baseline to midline. Beneficiaries of non-farm economic activities had a $73.9 \%$ increase in income as a result of participation in the NFDP III. This was gathered from the beneficiaries during oral interviews 
three years after the project. Crop farmers had a $225 \%$ increase in income from baseline whilst livestock owners had a $315 \%$ increase in income. For non-farm economic activities, beneficiaries had $203 \%$ increased income as compared to their income at baseline.

Table 5

Analysis of Changes in Beneficiaries' Income

\begin{tabular}{|c|c|c|c|c|c|}
\hline & & Sokoto & State & & \\
\hline $\begin{array}{l}\text { Average } \\
\text { Income }\end{array}$ & $\begin{array}{l}\text { Baseline, } \\
2009\end{array}$ & Midline, 2011 & $\begin{array}{l}\% \text { increase } \\
\text { in income } \\
\text { (baseline to } \\
\text { midline) }\end{array}$ & $\begin{array}{l}\text { Incomes } 3 \\
\text { years after } \\
\text { NFDP III, } \\
2016\end{array}$ & $\begin{array}{l}\text { \% increase in } \\
\text { income } \\
\text { (baseline to } \\
3 \text { years after } \\
\text { project) }\end{array}$ \\
\hline Crop farmers & $\$ 83,791.00$ & $\mathrm{~N} 177,660.20$ & $112 \%$ increase & $\$ 273,000.00$ & $225 \%$ increase \\
\hline $\begin{array}{l}\text { Livestock } \\
\text { owners }\end{array}$ & $\mathrm{N} 67,434.50$ & $\mathrm{~N} 112,548.50$ & $66.9 \%$ increase & $\mathrm{N} 280,106.00$ & $315 \%$ increase \\
\hline $\begin{array}{l}\text { Non-farm } \\
\text { income }\end{array}$ & $\mathrm{N} 58,634.50$ & $\mathrm{~N} 102,000.00$ & $73.9 \%$ increase & $\mathrm{N} 178,000.39$ & $203 \%$ increase \\
\hline
\end{tabular}

Source: Baseline and Midline Surveys (SOSFDO, 2009; 2011); Researchers' Survey, 2017

Table 6

Analysis of Extent of Food Security amongst NFDP III Beneficiaries

\begin{tabular}{lllll}
\hline \multicolumn{5}{c}{ Kaduna State } \\
$\begin{array}{lllll}\text { Ability to feed } \\
\text { families }\end{array}$ & $\begin{array}{l}\text { Before } \\
\text { NFDP III }\end{array}$ & $\begin{array}{l}\text { During NFDP } \\
\text { III }\end{array}$ & $\begin{array}{l}\text { Three years } \\
\text { after NFDP III }\end{array}$ & $\begin{array}{l}\text { Improvements on the } \\
\text { extent of food security/ } \\
\text { reduction in the rate of } \\
\text { hunger }\end{array}$ \\
\hline With great difficulty & 40 & 8 & 14 & -26 \\
With difficulty & 34 & 5 & 16 & -18 \\
With some difficulty & 30 & 13 & 20 & $-10 \quad=54(42.2 \%)$ \\
Fairly easily & 16 & 55 & 45 & 29 \\
Very easily & 8 & 47 & 33 & 25 \\
\hline Total & 128 & 128 & 128 & $108(84.4 \%)$ \\
\hline
\end{tabular}

Source: Researchers' Survey, 2017 
As can be seen in Table 6, the number of respondents in Kaduna State who experienced great difficulty and difficulty in feeding their families before participation in the NFDP III project were significantly reduced from 40 and 34 to 8 and 5, respectively as a result of their participation. Meanwhile, their numbers increased slightly three years after the project to 14 and 16, respectively. Similarly, a total of 30 beneficiaries who experienced some difficulty feeding their families before participation were reduced to 13 during the project's life span; however three years after the project this number had increased to 20. In contrast, 15 and 8 of the beneficiaries who fed their families fairly easily and very easily increased significantly to 55 and 47, respectively during the project. However, three years after the project these numbers were slightly reduced to 45 and 33, respectively. Project sustainability needs to be reinforced to maintain its impact. These results showed that on the whole, the food security situation of $84.4 \%$ of the beneficiaries from Kaduna State had improved significantly.

Table 7

Analysis of Extent of Food Security amongst NFDP III Beneficiaries

\begin{tabular}{llllll}
\hline \multicolumn{5}{c}{ Sokoto State } \\
\hline $\begin{array}{l}\text { Ability to feed } \\
\text { families }\end{array}$ & $\begin{array}{l}\text { Before } \\
\text { NFDP III }\end{array}$ & $\begin{array}{l}\text { During } \\
\text { NFDP III }\end{array}$ & $\begin{array}{l}\text { 3 years after } \\
\text { NFDP III }\end{array}$ & $\begin{array}{l}\text { Improvements on } \\
\text { the extent of food } \\
\text { security }\end{array}$ \\
\hline With great difficulty & 50 & 7 & 10 & -40 \\
With difficulty & 33 & 8 & 15 & -18 & -3 \\
With some difficulty & 28 & 12 & 25 & 29 & $=61(52.1 \%)$ \\
Fairly easily & 3 & 47 & 37 & 25 & \\
Very easily & 3 & 43 & 30 & $115(98.3 \%)$ \\
\hline Total & 117 & 117 & 117 & & \\
\hline
\end{tabular}

Source: Researchers' Survey, 2017

As can be seen in Table 7, the number of the respondents in Sokoto State, who experienced great difficulty and with difficulty in feeding their families before participation in the project were significantly reduced from 50 and 33 to 7 and 8 , respectively as a result of participation. However, their numbers increased slightly three years after the project to 10 and 15, respectively. Similarly, a total of 28 beneficiaries who experienced some difficulty in feeding their families before participation dropped to 12 during the project's life span; but three years after the project, the number had increased to 25 . In contrast, 3 and 3 of the beneficiaries who fed their families fairly easily and very easily appreciated significantly to 47 and 43, respectively during the project. However, three years after the project these numbers were slightly reduced to 55 and 47 and subsequently reduced to 37 
and 30, respectively. Project sustainability needs to be reinforced to maintain its impact. These results showed that generally, the food security situation of $52.1 \%$ of the beneficiaries from Sokoto State had improved significantly.

Table 8

Analysis of Socio-economic Conditions of NFDP III Beneficiaries

\begin{tabular}{lllll}
\hline \multicolumn{5}{c}{ Kaduna State } \\
\hline $\begin{array}{l}\text { Ability to make ends meet-clothing, } \\
\text { health care, diet and nutrition, } \\
\text { children's schooling, safe drinking } \\
\begin{array}{l}\text { water and sanitation facilities } \\
\text { Less than adequate }\end{array}\end{array}$ & NFDP III & $\begin{array}{l}\text { During } \\
\text { NFDP III }\end{array}$ & $\begin{array}{l}3 \text { years } \\
\text { after } \\
\text { NFDP III }\end{array}$ & $\begin{array}{l}\text { Improvement } \\
\text { in well-being of } \\
\text { beneficiaries }\end{array}$ \\
$\begin{array}{l}\text { Just adequate } \\
\text { More than adequate }\end{array}$ & 50 & 9 & 21 & -29 \\
\hline Total & 33 & 58 & 49 & 16 \\
\hline
\end{tabular}

Source: Researchers' Survey, 2017

As can be seen in Table 8, 50 of the beneficiaries who were less than adequate in their ability to make ends meet (clothing, health care, diet and nutrition, children's schooling, safe drinking water and sanitation facilities) dropped to 9 as a result of their participation in NFDP III; despite this, the number increased significantly to 21 , three years after the project. In contrast, 33 respondents who were just adequate, to make ends meet increased significantly to 58 as a result of their participation. However, this number dropped slightly to 49 , three years after the project. A total of 8 beneficiaries who were more than able to make ends meet prior to their participation in the project increased dramatically to 61 as a result of their participation, although this number dropped slightly to 58, three years after the project. On the whole, the results showed that the living conditions of $74.2 \%$ of the beneficiaries from Kaduna State had improved significantly.

As shown in Table 9, 80 of the beneficiaries who were less than adequate in their ability to make ends meet (clothing, health care, diet and nutrition, children's schooling, safe drinking water and sanitation) dropped dramatically to 13 as a result of participation in NFDP III; despite this the number increased to 19, three years after the project. In contrast, 35 of the beneficiaries who were just adequate to make ends meet increased significantly to 58 as a result of their participation. Subsequently, this number increased slightly to 62 , three years after the project. Beneficiaries who were more than able to make ends meet prior to their participation in the project increased dramatically from 2 to 46 as a result of their participation although this number dropped slightly to 36 , three years after the project. On 
the whole, the results showed that the living conditions of $95.7 \%$ of the beneficiaries from Sokoto State had improved significantly.

Table 9

Analysis of Socio-economic Conditions of NFDP III Beneficiaries

\begin{tabular}{|c|c|c|c|c|}
\hline \multicolumn{5}{|c|}{ Sokoto State } \\
\hline $\begin{array}{l}\text { Ability to make ends meet-clothing, } \\
\text { health care, diet and nutrition, } \\
\text { children's schooling, safe drinking } \\
\text { water and sanitation }\end{array}$ & $\begin{array}{l}\text { Before } \\
\text { NFDP } \\
\text { III }\end{array}$ & $\begin{array}{l}\text { During } \\
\text { NFDP III }\end{array}$ & $\begin{array}{l}3 \text { years after } \\
\text { NFDP III }\end{array}$ & $\begin{array}{l}\text { Improvement } \\
\text { in well-being of } \\
\text { beneficiaries }\end{array}$ \\
\hline Less than adequate & 80 & 13 & 19 & -61 \\
\hline Just adequate & 35 & 58 & 62 & 27 \\
\hline More than adequate & 2 & 46 & 36 & 24 \\
\hline Total & 117 & 117 & 117 & $112(95.7 \%)$ \\
\hline
\end{tabular}

Source: Researchers' Survey, 2017

\section{Hypothesis Testing}

Level of provision of small-scale community-owned infrastructure has no significant impact on the incidence of poverty of NFDP III beneficiaries in Kaduna and Sokoto states, Nigeria.

Table 7

Level of Provision of SCI and Reduction of Poverty amongst NFDP III Beneficiaries

\begin{tabular}{lcccccc}
\hline Variable & N & Mean & Std.dev & $\begin{array}{l}\text { Correlation } \\
\text { index }\end{array}$ & Df & P \\
\hline Poverty reduction & 245 & 19.35 & 2.88 & & & \\
& & & & $0.702 * *$ & 243 & 0.000 \\
$\begin{array}{l}\text { Small-scale community-owned } \\
\text { infrastructure }\end{array}$ & 245 & 28.65 & 3.77 & & & \\
\hline
\end{tabular}

*. Correlation is significant at the 0.05 level (2-tailed) 
Results of the PPMC statistics showed that the level of provision of SCI has significant impact on the incidence of poverty of NFDP III beneficiaries in Kaduna and Sokoto states, Nigeria. This is because the calculated p-value of 0.000 is less than the 0.05 alpha levels of significance at a correlation index $\mathrm{r}$ level of 0.702 at $\mathrm{df} 243$. This shows that there is a strong and positive correlation between SCI and poverty reduction and the nature of the relationship between the two (2) associated variables is directly proportional. That is, the higher the level of provision of SCIs, the greater the impact of NFDP III on the living conditions of the beneficiaries. Therefore the null hypothesis which states that level of provision of SCIs has no significant impact on the incidence of poverty of NFDP III beneficiaries in Kaduna and Sokoto states, Nigeria, is hereby rejected.

\section{Summary of Major Findings}

The study found that in the efforts towards reducing the incidence of rural poverty, NFDP III has promoted the provision of SCIs in order to improve the living conditions of the beneficiaries which significantly increased their income, improved the food security situation and dramatically enhanced the socio-economic well-being of the beneficiaries. For example, the income of crop farmers in Kaduna State increased by $79.5 \%$ at midline ( $\mathrm{N} 116,663.50$ to $\mathrm{N} 209,457.00)$ and increased by $199 \%$ ( $N 166,663.50$ to $\mathrm{N} 349,332.00$ ) three years after the project. The average income of livestock owners increased by $32.13 \%$ at midline ( $\$ 92,190.20$ to $\$ 121,820.00$ ) and increased by $221 \%$ ( $\$ 92,190.20$ to $\$ 296$, $144.00)$ three years after the project. Non-farm income of beneficiaries increased by $14.7 \%$ at midline ( $\mathrm{N} 135,150.00$ to $\mathrm{N} 155,042.00)$ and increased by $55.5 \%(\mathrm{~N} 135,150.00$ to $\mathrm{N} 210,280.10$ ) three years after the project. The average income of crop farmers in Sokoto State increased by $112 \%$ at midline ( $\mathrm{N} 83,791.00$ to $\mathrm{N} 177,660.20)$ and increased by $225 \%$ ( $\$ 83,791.00$ to $\$ 273,000.00$ ) three years after the project. Similarly, the average income of livestock owners increased by $66.9 \%$ ( $¥ 67,434.50$ to $\$ 112,548.50$ ) at midline and increased by $315 \%$ ( $\mathrm{N} 67,434.50$ to $\mathrm{N} 280,106.00)$ three years after the project. Non-farm income increased by $73.9 \%$ at midline ( $\$ 58,634.50$ to $\mathrm{N102,000.00)}$ ) and increased by $203 \%$ ( $\mathrm{N} 58,634.50$ to $\mathrm{N} 178,000.39$ ) three years after the project.

The extent of the food security situation of $84.4 \%$ of the beneficiaries in Kaduna State and $98.3 \%$ in Sokoto State had improved tremendously. The rate of hunger amongst the project beneficiaries were equally reduced, by $42.2 \%$ in Kaduna State and $52.1 \%$ in Sokoto State. In addition, the socio-economic conditions of the project beneficiaries in Kaduna and Sokoto states improved significantly by $74.2 \%$ and $95.7 \%$, respectively.

The study also revealed that there were significant differences in the level of provision of SCIs amongst the project beneficiaries with the beneficiaries from Kaduna State having an edge over those from Sokoto State because of income differential amongst the beneficiaries. Beneficiaries from Kaduna State had the resources to raise the 10\% shares of counterpart funding more than those from Sokoto State. 


\section{Conclusion and Recommendations}

In essence, this study was prompted by the ever-increasing infrastructural deficits especially in the countryside of Nigeria on the one hand and the ever increasing incidence of rural poverty in the north-west geo-political zone on the other. Based on the findings of the study, there is a strong and positive correlation between improved infrastructures and poverty reduction.

The need for sustaining the impetus created by NFDP III on poverty reduction in Nigeria has become pertinent for the three tiers of government i.e. federal, state and local. This is a matter of grave concern and to extend their commitment in the fight against poverty beyond those of merely facilitating the provision of rural infrastructure to improving the levels of provision, maintenance and management. The federal government should therefore increase allocation of state and local government funds for the provision and maintenance of rural infrastructural facilities whilst local governments should facilitate the provision and monitor the execution and/or maintenance of community-owned projects in their respective domains.

Although the targeting mechanism of NFDP III had attempted to include the marginalized stratum of the society, many poorest of the poor were not able to participate in the project because they could not in particular raise the 10\% shares of beneficiaries' counterpart funding requirements for SCIs. Therefore the study suggests for a reduction of $5 \%$ on rural infrastructure to be implemented in other subsequent programmes. There is the need to streamline credit service providers (CSPs) within the framework of agricultural and antipoverty programmes such as micro-finance institutions. User charges should be enforced for certain infrastructure support sub-components to improve the level of maintaining the established infrastructures.

\section{References}

Adenuga, A. H., Babatunde, R. O., Olagunju, F. I., \& Oladajo A, O. (2012). Effect of road infrastructure on farm production in Oyo State. Journal of Economic Development, $37(1), 32-40$.

Adeoye, A., Yusuf S. A., Balogun, O. L., \& Carim-sanni, A. (2011). Rural infrastructural development and profitability of famers under NFDP II in Oyo State, Nigeria. World Rural Observation, 3(2), 142-148.

Adepoju, A. A., \& Salman, K. K. (2013). Increasing agricultural productivity through rural infrastructure: Evidence from Oyo and Osun States, Nigeria. International Journal of Applied Agricultural and Apicultural Research, 1(10), 10-20.

AfDF. (2003). A Republic of Nigeria Fadama Development Project Technical Appraisal Report. African Development Bank. 
Ale, M. O., \& Abisuwan, O. T. A. (2011). Rural infrastructural development, food security and city congestion in Nigeria. Journal of Research in National Development, 9(1), 124-130.

Calderón, C., \& Serve, L. (2008). Infrastructure and Economic Development in Sub-Saharan Africa. Policy Research Working Paper, 4712. Washington, D. C.: World Bank.

Calderón, C., \& L. Servén, L. (2010). Infrastructure and Economic Development in SubSaharan Africa, Journal of African Economies, 19(s1), 113-187, Retrieved from https://ideas.repec.org/a/oup/jafrec/v19y2010isuppl_1p13-87.html

FGN. (2009). Project Implementation Manual (Annexure, 2): Third National Fadama Development Project. Federal Ministry of Agriculture and Water Resources at www. fadama.net

Frischman, B. M. (2005). An economic theory of infrastructure and common management. Minnesota Law Review, 89(917), 917-976.

Gannon, K., Gwillian, Z., Liu, Z., \& Malmberg, C. (2001). Transport: Infrastructure and services. Chapter 4.2 in Poverty Reduction Strategy Sourcebook, Vol. 2 (Macro and Sectoral issues). Washington, D.C.: World Bank.

Grossman, J. B. (1994). Evaluating social policies: Principles and U.S. experience. The World Bank Research Observer, 9(2), 159-180.

Hastuti, A. T. (2016). Analisis kemiskinan dan ketersediaan infrastruktur di pedesaan kawasan jalan lintas selatan Jawa Timur. Malang: Universitas Brawijaya.

IFAD. (2011). Rural poverty in Nigeria. International Fund for Agricultural Development. Retrieved from http://www.ruralpovertyportal

KDSFDO. (2014). Compendium of Project Implementation (2009-2013). Kaduna State Fadama Development Office, Kaduna.

Kifle, A. (2012). Rural roads and development: Evidence from Ethiopia. Wondemua and John Weissb. European Journal of Transport and Infrastructure Research, 12(4), 417-436.

Khwaja, A. (2001). Can good projects succeed in bad communities? Collective action in the Himalayas. Cambridge, Mass., U.S.A.: Harvard University Press.

Krejcie, R. V., \& Morgan, D. W. (1970). Determining sample size for research activities. Educational and Psychological Measurements, 30, 607-610.

Likert, R. (1932). A technique for the measurement of attitudes. Archives of Psychology. Retrieved from https://scholar.google.com/scholar?hl=en\&as_sdt=0\%2C5\&q=Liker $\mathrm{t} \% 2 \mathrm{C}+\mathrm{R} .+\% 281932 \% 29 .+\mathrm{A}+$ technique + for + the + measurement + of + attitudes.\&btnG $=\# \mathrm{~d}=\mathrm{gs} \_$cit\&u=\%2Fscholar $\% 3 \mathrm{Fq} \% 3 \mathrm{Dinfo} \% 3 \mathrm{AShrXkx1Sqi4J} \% 3$ Ascholar.google.c om $\% 2$ F\% $\%$ output $\% 3$ Dcite $\% 26$ scirp $\% 3$ D0\%26hl\%3Den

Madu, I. A. (2007). The underlying factors of rural development patterns in Nsukka Region of South-Eastern Nigeria. Journal of Rural and Community Development, 2(1), 110 122.

Marinho, E., Campelo, G., Franca, J., \& Araujo, J. (2017). Impact of infrastructure expenses in strategic sectors for Brazilian poverty, Economia, 18(2017), 2, 244-259. Elsevier Publishing.

NBS. (2012). Nigeria Poverty Profile Report-2010. Abuja: National Bureau of Statistics Publishers. 
Ogun, T. P. (2010). Infrastructure and Poverty Reduction: Implications for Urban Development in Nigeria. UNU-WINDER Working Paper, 43. Marc, o.

Olagunju, F. I., Ayunde, O., Adewumi, M. O., \& Adesiji, C.A. (2014). Effect of rural road and markets infrastructure on income of farming household in Osun States: Implication for sustainable development. Ethiopian Journal of Research and Development, 2(4), 123-134.

Ostrom, E. (1990). Governing the commons: The evolution of institutions for collective action. New York: Cambridge University Press.

Prawesti, P. A., \& Hermawan, R. (2017). Infrastructural development and poverty reduction in Java, Indonesia 2002-2012. JPAS 1(3), 71-79.

Rossi, P. H., Lipsey, M. W., \& Freeman, H. E. (2004). Evaluation: A systematic approach (7th ed.). London: Sage.

Schweikert, A., \& Chinowsky, P. (2012). National infrastructure planning: A holistic approach to policy development in developing countries. Paper presented at the Engineering Project Organizations Conference, Rheden. Retrieved from https://www. academia.edu/2755320/.

World Bank. (2016). World Bank: Nigeria-country at a glance. Retrieved from http:// www.worldbank.org/en/country/nigeria 